\title{
Organophosphate and carbamate poisonings in the northwest of Paraná state, Brazil from 1994 to 2005: clinical and epidemiological aspects
}

\author{
Alexandre Ferreira ${ }^{1 *}$, Elisangela Maroco ${ }^{2}$, Mauricio Yonamine ${ }^{1}$, Magda Lúcia Félix de Oliveira $^{2}$ \\ 'Departamento de Análises Clínicas e Toxicológicas, Faculdade de Ciências Farmacêuticas, Universidade de São \\ Paulo, ${ }^{2}$ Universidade Estadual de Maringá
}

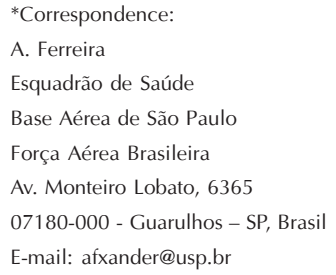

In the present study, clinical and epidemiological aspects of 529 intoxication cases of organophosphate or carbamate pesticides in the northwest of the state of Paraná, Brazil, over a twelve-year period (1994-2005), are presented. One hundred-five of 257 patients (40.8\%) who attempted suicide were admitted to Intensive Care Units (ICUs), with an average hospital stay of two days (range 1-40 days). Men corresponded to 56.4\% of the cases of suicide attempts and sixteen individuals died. One hundred-forty patients intoxicated due to occupational exposure were all young adults and nine of them were admitted to ICU, with average hospital stays of eight days (range 1-16 days). Of these cases, two patients died. One hundred twenty-four patients intoxicated due to accidental exposure were mainly children and had a hospital average stay of four days. Twenty patients were admitted to the $I C U$, and one of them died. Overall complications included respiratory failure, convulsions, and aspiration pneumonia. Deliberate ingestion of organophosphates and carbamates was much more toxic than occupational and accidental exposure. Men aged 15-39 years were the most likely to attempt suicide with these agents and had more prolonged ICU with significant complications and mortality.
Uniterms

- Organophosphate pesticides/toxicity

- Carbamate/toxicity

- Anticholinesterase pesticides/occupational exposure

- Acute intoxication

\section{INTRODUCTION}

Pesticides are a broad range of substances most commonly used for control agricultural pests and in public health programs to control the transmission of vector borne diseases. Nowadays, hundreds of active ingredients and thousands of formulations are available in the world market (Meister, 1999). About 1.5 million tonnes of pesticides are manufactured every year, producing a business worth US $\$ 30$ billion (Wood, 2001; Eddleston et al., 2002). However, due to their chemical structures and the nature of their biological activity, pesticides have brought potential risks 
to humans in many situations. Several reports have demonstrated that pesticide poisoning has been a long-standing problem through Africa (Ohayo-Mitoko et al., 2000; Dong, Simon, 2001), Asia (Weissmann-Brenner et al., 2002; Nagami et al., 2005; Van der Hoek, Konradsen, 2006; Sungurlekin et al., 2006), Europe (Kara et al., 2002; Nisse et al., 2002; Davanzo et al., 2004), and Americas (Lu et al., 2000; Stallones, Beseler, 2002; Bonner et al., 2005; Pires et al., 2005).

An estimated of 1 to 5 million cases of pesticides poisoning occur every year, resulting in several thousands of fatalities mainly among agricultural workers. Most of these poisonings occur in developing countries where the lack of hygiene, information or adequate control has created unsafe working conditions. In spite of these countries represent only $25 \%$ of global pesticide consumption, they account for approximately $99 \%$ of the related deaths (United Nations Press Release, 2004).

In Brazil, data from Sistema Nacional de Informações Tóxico-Farmacológicas (SINITOX) showed that 12,788 cases of pesticide poisoning were recorded in the twenty-nine of the thirty-three Poisoning Control Centers spread out the country in 2003. Of these cases, 227 (1.8\%) resulted in deaths. Accidental poisoning (individual and group poisoning, and environmental poisoning) was involved in 4,745 cases (37.1\%), suicide attempts in 5,437 (42.5\%) and occupational poisoning corresponded to 1,866 cases (14.6\%) (Sinitox, 2003). In this data of intoxication cases, it was considered pesticides of agricultural and household use and rat poisons. In Brazil, it is still common the misuse of carbamate insecticides of restrict agricultural use as household rodenticide (mainly aldicarb) regionally known as "chumbinho" (Ragoucy-Sengler et al., 2000; Corrêa et al., 2004).

The majority of pesticide deaths recorded in worldwide hospital surveys are related to self-poisoning (Eddleston, 2000; Eddleston et al., 2002). Accidental poisoning can occur at home when pesticides are not well stored and mistaken for soft-drinks or food products. Children are often the majority of victims (IPCS, 1993). Intentional poisoning can also occur by deliberate ingestion of pesticides as a means of suicide (Hashim et al., 2002). Although some studies have reported that agricultural workers are at higher risk of suicide compared to other occupational groups (Stallones et al., 1995), this relationship was not clearly observed in a study conducted in Brazil (Pires et al., 2005). Another possibility of poisoning can be due to the excessive occupational exposure to pesticides that can be promptly absorbed through inhalation or by dermal contact. The severity of intoxication is directly related to the type of the pesticide involved, magnitude, duration and frequency of exposure. Its intensity is extremely variable depending on the size of the area worked on, mode of application, climatic conditions as well as operator skills and the use of appropriate personal protective equipment (Hashim et al., 2002).

Among pesticides, organophosphates and carbamates, compounds which are known as anticholinesterase agents, represent the main classes involved in cases from mild to severe intoxications. Anticholinesterase agents have in common the same mechanism of action but they arise from two different chemical classes: the derivatives of phosphoric, phosphorothioic, phosphorodithioic and phosphonic acids (organophosphates) and those of carbamic acid (carbamates). These compounds inhibit acetylcholinesterase enzymes, thereby causing elevations in the levels of the neurotransmitter acetylcholine leading to an acute cholinergic syndrome. Clinical signs of intoxication include increased secretions, bronchoconstriction, miosis, gastrointestinal cramps, diarrhea, bradycardia, muscle fasciculation, central nervous system depression, convulsions, cyanosis and coma (Ecobichon, 2001). Like organophosphates, carbamates inhibit cholinesterase enzymes and therefore share similar symptoms, although their poisoning tends to have shorter duration (Fishel, Andre, 2002).

Acute effects appear immediately or within 24 hours after exposure. They are more accurately diagnosed than the delayed effects because they tend to be more evident. Generally they are reversible if appropriate medical care is given promptly. However it may be fatal if not (Fishel, Andre, 2002).

In spite of anticholinesterase pesticides intoxication being an important problem in Brazil, there is limited information regarding the management and outcomes of poisoned patients in this country. So, in the present study, the management and outcomes of patients suspected of organophosphate or carbamate poisoning in some municipalities of northwest of Paraná, Brazil, over a twelve-year period (1994-2005), are presented. The patients were attended at Hospital Universitário Regional de Maringá (HURM), located in Maringá, the third most populated city of Paraná state (IBGE, 2005).

\section{MATERIAL AND METHODS}

According to the latest national census performed in 2000 by the Instituto Brasileiro de Geografia e Estatística (IBGE), a Brazilian governmental institution responsible for geographical studies in the country, the state of Paraná had a population of $9,563,458$ inhabitants, with $81.4 \%$ living in urban and $18.6 \%$ in rural areas (IBGE, 2000).

Nowadays, Paraná is playing an important role in Brazilian agricultural production. In spite of occupying only 
$2.3 \%\left(199,324 \mathrm{~km}^{2}\right)$ of the Brazilian territorial area, it is responsible for about $23.4 \%$ of the national production of grains, mainly soy. Other products include maize, bean, coffee, wheat, oats, rye and barley. Small and medium crops, managed by familial groups, are predominant in its agricultural system. More than $85 \%$ of the properties are not bigger than 0.5 square kilometers. Paraná is a great consumer of commercial pesticides (the second greatest consumer in Brazil) and consequently cases of intoxication are frequently reported in this region (Polastro, 2005). Organophosphates are the second group of pesticides most used in Paraná state in cultures soy. More than 800 ton. of active ingredient (about 1800 ton. of formulations) were applied in a soy cultivated area of approximately 20,000 square kilometers during the period of 1998/1999 (IBGE, 1999).

Reports of poisoning and suicide attempts involving organophosphate and carbamate pesticides using data from the Poisoning Control Center of Hospital Universitário Regional de Maringá (HURM) over a twelve-year period (from January 1994 to December 2005) were evaluated. In this retrospective study, the management and outcomes of 529 patients are presented. Children and adults of both sexes attended at HURM with diagnosis of anticholinesterase intoxication were included in the study. Cases were identified by accessing the unit medical records of all patients coded with a discharge diagnosis of anticholinesterase poisoning at the hospital. Diagnosis was based in the laboratorial measurements of blood cholinesterase activity, according to the colorimetric method (bromothymol blue) described by Midio and Silva (1995), and the observation of clinical features of a cholinergic syndrome. Unfortunately, by this way, it was not possible to confidently distinguish between carbamate and organophosphate poisonings. In general, miosis in association with fasciculations is pathognomonic of the syndrome, particularly in adults; lachrymation, salivation, bronchorrhoea and excessive sweating along with bradycardia provided supportive evidence of anticholinesterase poisoning (Kamanyire, Karalliedde, 2004). In some cases, diagnosis was made from the history taken either from the patient or from the patient's relatives/colleagues regarding the agent involved in the exposure. Data was collected by means of an interview of the patients or their fellow people by a health professional of the hospital and included age, sex and circumstances of the poisoning. The identification of the insecticide involved in each case (when possible), the time of admission to the hospital, signs and symptoms of poisoning, management and further complications were also recorded.

Following diagnosis, grading of intoxication severity was performed with the aim to identify patients who should receive treatment in intensive care using adequate doses of anticholinergic drugs. Severity of poisoning was classified using the revised grading system for anticholinesterase pesticide poisoning proposed by Bardin et al. (1994) (Table I). However, it is important to emphasize that it may not be applicable less than 8 hours after poisoning. Treatment was implemented as soon as the diagnosis of either organophosphate or carbamate poisoning was made. Gastric lavage was performed and activated charcoal was administered to patients who ingested the compounds. Atropine sulphate was administered intravenously in repeated doses or continuous infusion to patients with cholinergic syndrome. Pralidoxime was administered to patients with recognized intoxication by organophosphates, when available.

Data collection included age, sex, circumstances of the poisoning, identification of the insecticide, time of admission to the hospital, signs and symptoms of poisoning, treatment and mortality rate.

TABLE I - Organophosphate poisoning grading criteria (Bardin et al., 1994)

\begin{tabular}{lc}
\hline Poisoning & Sign/Symptoms \\
\hline Mild & Normal level of consciousness; \\
Severe & mild secretions; few fasciculations \\
& Altered level of consciousness; \\
& copious secretions; \\
Life-threatening & generalized fasciculations. \\
\hline
\end{tabular}

\section{RESULTS}

In the present study, there were 171 identified cases of organophosphate intoxication. In 9 cases, associations of organophosphates were identified (Table II). With reference to carbamate pesticides, the specific substance was identified in 167 cases of intoxication (Table III). In 191 cases, the identity of the anticholinesterase pesticides could not be carried out successfully.

There was no correlation between a specific pesticide and the severity of poisoning. The pesticides were evenly distributed among severity classifications. The only variable that correlated with severity was the fact whether the poisoning was deliberate (more severe) or accidental (less severe). There was no significant change in the frequency of intoxication cases over the twelve-year period, neither any seasonal variation.

Attempts to suicide represented $48.6 \%$ of the total poisonings. There were 145 male and 112 female in the group; aged 15-84 years (mean 31). More than half of the attempted suicide patients $(65.0 \%)$ were in the $15-39$ years- 
old group. It was observed that almost all of attempted suicide patients ingested the insecticide, with exception of one who injected the organophosphate by an unknown parenteral via.

TABLE II - Quantity of organophosphate intoxication cases occurred in the northwest of the state of Paraná, Brazil, over a twelve-year period (1994-2005), in which the etiological agent could be identified

\begin{tabular}{lc}
\hline Organophosphate insecticide & Cases \\
\hline Monocrotophos & 44 \\
Methylparathion & 35 \\
Methamidophos & 33 \\
Chlopyrofos & 12 \\
Malathion & 8 \\
Diazinon & 6 \\
Dichlorvos & 5 \\
Profenofos & 4 \\
Triazophos & 3 \\
Trichlorfon & 3 \\
Dicrotophos & 2 \\
Pyrazophos & 1 \\
Temephos & 1 \\
Dimethoate & 1 \\
Acephate & 1 \\
Formothion & 1 \\
Malathion & 1 \\
Phentoate & 1 \\
Monocrotophos + methamidophos & 4 \\
Monocrotophos + methylparathion & 3 \\
Monocrotophos + chlorpyrophos & 1 \\
Monocrotophos + acephate & 1 \\
\hline
\end{tabular}

TABLE III - Quantity of carbamate intoxication cases occurred in the northwest of the state of Paraná, Brazil, over a twelve-year period (1994-2005), in which the etiological agent could be identified

\begin{tabular}{lc}
\hline Carbamate insecticide & Cases \\
\hline Propoxur & 83 \\
Aldicarb & 34 \\
Carbofuran & 26 \\
Methomyl & 18 \\
Carbaryl & 3 \\
Thiodicarb & 2 \\
Pirimicarb & 1 \\
\hline
\end{tabular}

One hundred-forty patients intoxicated due to occupational exposure were all young adults and nine of them were admitted to Intensive Care Unit (ICU), with average hospital stay of eight days (range 1-16 days). In general, intoxicated workers were not using personal protective equipments during their labor activity.

The accidental exposure group comprised 78 children and 46 adults. Children ranged in age from 1-14 years, with the majority (62.8\%) aged two years old. The exposure was predominantly by ingestion (51.6\%). Adults were poisoned by inhalation $(95.7 \%)$ and percutaneous exposure (4.3\%), and in all cases the victims developed clinical signs. Of the attempted suicide group, $40.9 \%$ required admission to the ICU, compared to $6.4 \%$ of the occupational and $16.1 \%$ of the accidental groups. The summary of these findings are presented in Table IV.

TABLE IV - Summary of notifications of 521 patients over twelve-years (1994-2005) in the Poisoning Control Center of Hospital Universitário Regional de Maringá (HURM), state of Paraná, Brazil

\begin{tabular}{|c|c|c|c|}
\hline Poisoning & $\begin{array}{l}\text { Suicide } \\
\text { attempts }\end{array}$ & $\begin{array}{l}\text { Circumst } \\
\text { Occupati }\end{array}$ & cidental \\
\hline Number & 257 & 140 & 124 \\
\hline \multicolumn{4}{|l|}{ Admitted } \\
\hline $\begin{array}{l}\text { ICU } \\
\text { Ward } \\
\text { Hospital stay (days) }\end{array}$ & $\begin{array}{c}105 \\
152 \\
1-40 \\
\text { (average 2 }\end{array}$ & $\begin{array}{r}09 \\
131 \\
1-16 \\
\text { ) average }\end{array}$ & $\begin{array}{c}20 \\
104 \\
1-9 \\
\text { erage 4) }\end{array}$ \\
\hline \multicolumn{4}{|l|}{ Severity of poisoning } \\
\hline $\begin{array}{l}\text { Mild } \\
\text { Severe } \\
\text { Life threatening } \\
\text { Mortality }\end{array}$ & $\begin{array}{l}98 \\
80 \\
79 \\
16\end{array}$ & $\begin{array}{c}108 \\
30 \\
02 \\
02\end{array}$ & $\begin{array}{l}86 \\
25 \\
13 \\
01\end{array}$ \\
\hline
\end{tabular}

Four cases not shown in Table IV presented other circumstances of intoxication: two patients were victims of homicide or attempt and other two misused the insecticide as head lice poison. In other four cases, the circumstances of intoxication were ignored.

With the gradual progress of the anticholinesterase intoxication, 20 patients died (14 males and six females): 16 by effective suicide, two patients due to occupational exposure, one patient in case of accidental poisoning, and one victim of homicide poisoning (not showed in Table IV). In these fatal cases, the exposure was mainly by ingestion, except the two occupational cases, where individuals were poisoned by inhalation and percutaneous exposure. In nine cases, monocrotophos was the agent involved in the fatal intoxications; methyl-parathion and propoxur were identified 
in one and two cases each, respectively. In eight cases, the etiologic agent was not found out. Atropine had been administered in all of them and pralidoxime was administered in cases where organophosphate intoxication had been previously identified (ten cases). These patients responded to a mortality rate of $3.8 \%$ in the overall cases of intoxication.

In the group of attempted suicide patients, vomiting was the most common sign (40.5\%) followed by nausea $(23.0 \%)$, miosis $(21.1 \%)$, and salivation (19.3\%). Fasciculations were present in $10.7 \%$ and bradycardia in only $3.8 \%$ of the patients. Signs and symptoms of anticholinesterase intoxication were less common in the accidental and occupational groups. The overall signs and symptoms observed for each group of patients are shown in Table V.

Atropine was administered to all patients who presented muscarinic symptoms (increased secretions, vomiting, nausea, miosis, abdominal pain, diarrhea, urination, bradycardia) (Ecobichon, 2001). It was administered either as a continuous infusion or intermittent dosing according to the features of adequate atropinization such as dry mouth, dry tongue and dilatation of pupils. The duration of atropine treatment ranged from 1-10 days. Pralidoxime was administered, when available, only in patients whose intoxication by organophosphates was known by their histories once its use is contraindicated in cases of carbamate poisoning. It was administered to $19 \%$ of the attempted suicide group, $14 \%$ of the accidental exposure group and $9 \%$ of the occupational group. It was initiated in the Emergency Department (ED) in $30 \%$ of the cases, as a 1-2 g bolus. Ninety-one patients in the ED and fifty-one in the ICU received pralidoxime infusions. The duration of the treatment ranged from 1-40 days (average 3 days). Diazepam was used in the management of convulsion and in the support of ventilatory care. It was also used prophylactically in cases of life-threatening poisoning.

Regardless of the symptomatic treatment, gastric lavage and activated charcoal administration were required for $39 \%$ and $28 \%$ of the patients, respectively. These pro-

TABLE V - Main signs and symptoms observed in organophosphate and carbamate intoxicated patients attended at Hospital Universitário Regional de Maringá (HURM)

\begin{tabular}{lccccc}
\hline Signs and symptoms & $\begin{array}{c}\text { Suicide attempt } \\
(\mathrm{n}=257)\end{array}$ & $\begin{array}{c}\text { Occupational } \\
(\mathrm{n}=140)\end{array}$ & $\begin{array}{c}\text { Accidental } \\
(\mathrm{n}=124)\end{array}$ & $\begin{array}{c}\text { Total } \\
(\mathrm{n}=521)\end{array}$ & $\%$ of the total \\
\hline Vomiting & 106 & 54 & 51 & 211 & 40.5 \\
Nausea & 55 & 45 & 20 & 120 & 23.0 \\
Miosis & 83 & 11 & 16 & 110 & 21.1 \\
Salivation & 72 & 7 & 21 & 101 & 19.3 \\
Abdominal pain & 41 & 32 & 9 & 82 & 15.7 \\
Vertigo & 33 & 38 & 8 & 79 & 15.2 \\
Headache & 19 & 42 & 15 & 76 & 14.5 \\
Sweating & 49 & 17 & 8 & 74 & 14.2 \\
Fasciculations & 37 & 12 & 7 & 56 & 10.7 \\
Diarrhea & 45 & 16 & 4 & 65 & 12.4 \\
Respiratory depression & 39 & 4 & 4 & 47 & 9.0 \\
Coma & 29 & 1 & 5 & 35 & 6.7 \\
Tachycardia & 19 & 5 & 10 & 35 & 6.7 \\
Respiratory failure & 28 & 1 & 4 & 33 & 6.3 \\
Hypertension & 16 & 4 & 10 & 30 & 5.7 \\
Weakness & 10 & 9 & 6 & 25 & 4.8 \\
Paleness & 16 & 1 & 3 & 20 & 3.8 \\
Bradycardia & 14 & 4 & 2 & 20 & 3.8 \\
Hypotension & 13 & 4 & 1 & 18 & 3.5 \\
Aspiration pneumonia & 15 & 0 & 3 & 18 & 3.5 \\
Convulsion & 12 & 1 & 3 & 17 & 3.3 \\
Urinary incontinence & 14 & 1 & 0 & 15 & 2.9 \\
Lachrymation & 2 & 2 & 5 & 8 & 1.5 \\
Blurred vision & 3 & 1 & 3 & 5 & 1.0 \\
Pulmonary edema & 1 & & & & 1.0 \\
\hline & & 3 & 5 & \\
\hline
\end{tabular}


cedures were performed in cases of supposed deliberate ingestion of pesticides. The management of anticholinesterase poisoning is summarized in Table VI (adapted from Bardin et al. (1994) and Karalliedde (1999)).

\section{DISCUSSION}

The occurrence of intoxication cases is certainly associated with high use of insecticides in the cultivation of grains such as soy, maize and coffee in the region of northwest Paraná. The most prevalent anticholinesterase insecticides observed were monocrotophos and methyl-parathion (in the group of organophosphates) and propoxur and aldicarb (in the group of carbamates). Coincidently, with the exception of propoxur, the other three compounds are the most toxic insecticides found in this study, considering their $\mathrm{LD}_{50}$ for rats, oral via (monocrotophos: $18 \mathrm{mg}$ / $\mathrm{kg}$; methyl-parathion: $14 \mathrm{mg} / \mathrm{kg}$; aldicarb: $0.5 \mathrm{mg} / \mathrm{kg}$ ) (Schvartsman et al., 1997).

Suicide attempts were the cause of pesticide poisoning in $48.6 \%$ of the studied cases compared with $64-67.4 \%$ in other developing countries (Agarwal, 1993; Saadeh et al., 1996) and 20-36\% in developed countries (Emerson et al., 1999; Weissmann-Brenner et al., 2002). In our study, men under 40 years old were prone to commit suicide with the organophosphate and carbamate insecticides with most serious consequences. The majority of the suicide attempt group required prolonged ICU permanence. The high incidence of suicide attempts and the high morbidity and mortality related to these cases suggest that preventive strategies to reduce suicide should be addressed to these chemicals, aiming the reduction of the undiscriminating access to these potent toxic agents. In fact, most deaths related to pesticide exposures recorded in hospital surveys are the result of self- poisoning. Studies have shown that pesticides are the most important method of self-poisoning in many rural regions and are associated with a high death rate (Eddleston, 2000).

The mortality rate found in our study $(3.8 \%)$ is similar to that found in developed countries (WeissmannBrenner et al., 2002; Roberts et al., 2005). Occupational exposure was the second cause of poisoning, followed by accidental exposure. Despite one patient having died after accidental intoxication, this kind of exposure appears to cause less severe poisoning, reflected by the much lower ICU admission rate, low complicate rate, and low incidence of severe signs and symptoms.

As expected, exposure by deliberate ingestion of the pesticides produced much more typical signs and symptoms of a cholinergic syndrome than those by occupational or accidental exposure. Vomiting, nausea, salivation and miosis are valuable indicators for the diagnosis of organophosphate and carbamate poisoning. These signs were observed in the majority of the intoxicated patients, and their frequency depends probably on the intensity of the exposure.

Poisoned patients in which deliberate ingestions of anticholinesterase pesticides were known, gastric lavage followed by activated charcoal administration were performed. The use of activated charcoal for conscious, nonvomiting patients who have ingested a substantial quantity of a poison within 1-2 hours must be encouraged. However, users must be aware of potential complications of its use, including aspiration pneumonitis and formation of charcoal bezoars (Jones, 1998).

Severe complications were more common in the group of patients who attempted suicide. The high incidence of respiratory failure and aspiration pneumonia reinforces the basic principles of emergency medicine that the airway control is the first priority in management. Exces-

TABLE VI - Summary of management of anticholinesterase intoxication (pediatric doses in parentheses)

\begin{tabular}{ll}
\hline Procedures & Emergency Treatment \\
\hline Decontamination & Gastrointestinal - activated charcoal. \\
& Cutaneous-water and alkaline soap (with precautions against self-contamination) \\
Specific treatment & Atropine - for any muscarinic symptoms. \\
& $2 \mathrm{mg}(0,05 \mathrm{mg} / \mathrm{kg})$ bolus followed by an infusion of $50 \mathrm{mg}$ atropine in \\
& $500 \mathrm{~mL} \mathrm{~N} / \mathrm{Sal}$ commenced at $20 \mathrm{~mL} / \mathrm{hour}(0.05 \mathrm{mg} / \mathrm{kg} / \mathrm{hour})$ and treated to effected, \\
& for sever or life-threatening poisoning. \\
& Pralidoxime $-1 \mathrm{~g}(20-50 \mathrm{mg} / \mathrm{kg}) \mathrm{bolus}$ \\
& over 30 minutes; followed by $500 \mathrm{mg} / \mathrm{hour}(10 \mathrm{mg} / \mathrm{kg} /$ hour $)$ infusion for severe \\
& or life-threatening organophosphate poisoning. \\
& Diazepam $-10 \mathrm{mg}(0.2 \mathrm{mg} / \mathrm{kg}) ;$ useful in the management of convulsion and \\
& in the support of ventilatory care; prophylactically for life-threatening poisoning. \\
& Respiratory and circulatory support as indicated. \\
General support &
\end{tabular}


sive salivation and bronchorrhoea, combined with respiratory and airway muscle paralysis, may have contributed to the incidence of pulmonary problems observed in this study.

Convulsions were not commonly observed in this study. Benzodiazepinies are the drugs of choice for treating convulsions. However, it is still unclear whether they should be given prophylactically in cases of life-threatening overdose. Despite the theoretical risks of respiratory failure and aspiration in patients already at risk with these complications, diazepam has been shown to prevent convulsions and improve morbidity (Karalliedde, 1999). In fact, the low incidence of convulsions in our series supports the prophylactic use of benzodiazepinies in cases of anticholinesterase intoxications.

\section{CONCLUSIONS}

Patients who attempted suicide with organophosphate and carbamate have long hospital permanence and severe health complications. Accidental and occupational exposures are much less likely to cause life-threatening toxicity. In particular, accidental exposure in children tended to be mild, reflecting the usually small exposure and minimal delays in recognizing the accident. Men with ages 15 - 39 seem to be the most likely to attempt suicide with these chemicals, probably reflecting their easy access to them. The low rate of mortality observed in this study (3.8\%), similar to that found in developed countries, is an indication that the management of poisoned patients with anticholinesterase pesticides has been appropriated. Additionally, with the identification of the main etiological agents involved in cases of intoxication and their circumstances, it will be possible that actions toward prevention and control of anticholinesterase pesticide can be taken to reduce the number of poisonings in the state of Paraná, Brazil.

\section{ACKNOWLEDGEMENT}

We thank the staff of Poisoning Control Center Hospital Universitário Regional de Maringá/Universidade Estadual de Maringá (Brazil) for permitting the collection of the data of poisonings and for their excellent assistance to develop this work.

\section{RESUMO}

Intoxicações por inseticidas organofosforados e carbamatos no noroeste do Paraná, Brasil, de 1994 a 2005: aspectos clínicos e epidemiológicos

No presente estudo são apresentados aspectos clínicos e epidemiológicos de 529 casos de intoxicação por inseti- cidas organofosforados e carbamatos ocorridos na região noroeste do Estado do Paraná, Brasil, no periodo de 1994 a 2005. A saber, 105 pessoas de 257 pacientes (40,8\%) que tentaram suicídio foram admitidas na Unidade de Tratamento Intensivo (UTI), com média de estadia hospitalar de 2 dias (de 1 a 40 dias). Pacientes do sexo masculino corresponderam a $56,4 \%$ dos casos de tentativa de suicídio e 16 individuos morreram. Todos os 140 pacientes intoxicados devido à exposição ocupacional eram adultos e 9 foram admitidos na UTI, com média de estadia hospitalar de 8 dias (de 1 a 16 dias). Destes casos, 2 pacientes faleceram. Dos 124 pacientes intoxicados devido à exposição acidental, a maioria era crianças e teve uma média de estadia hospitalar de 4 dias. Foram admitidos 20 pacientes na UTI e um morreu. Complicações gerais incluíram insuficiência respiratória, convulsões e pneumonia. A ingestão deliberada de organofosforados e carbamatos foi muito mais grave do que a intoxicação em decorrência da exposição ocupacional ou acidental. Homens na faixa de 15 a 39 anos foram os mais prováveis de tentar suicídio com esses agentes e tiveram admissões mais prolongadas na UTI com significativas complicações e mortalidade.

UNITERMOS: Inseticidas organofosforados/toxicidade. Carbamatos/toxicidade. Praguicidas anticolinesterásicos/ exposição ocupacional. Intoxicação aguda.

\section{REFERENCES}

AGARWAL, S.B. A clinical, biochemical, neurobehavioral, and sociopsychological study of 190 patients admitted to hospital as a result of acute organophosphorous poisoning. Environ. Res., v.62, n.1, p.63-70, 1993.

BARDIN, P.G.; VAN EEDEN, S.F.; MOOLMAN, J.A.; FODEN, A.P.; JOUBERT, J.R. Organophosphate and carbamate poisoning. Arch. Int. Med., v.154, n.13, p.1433-1441, 1994.

BONNER, M.R.; LEE, W.J.; SANDLER, D.P.; HOPPIN, J.A.; DOSEMECI, M.; ALAVANJA, M.C.R. Occupational exposure to carbofuran and the incidence of cancer in the agricultural health study. Environ. Health Perspect., v.113, n.3, p.285-289, 2005.

CORRÊA, C.L.; ZAMBRONE, F.A.D.; CAZARIN, K.C.C. Intoxicação por "chumbinho": um desafio para o diagnóstico clínico e para o tratamento. Rev. Bras. Toxicol., v.17, n.2, p.71-78, 2004. 
DAVANZO, F.; SETTIMI, L.; FARAONI, L.; MAIOZZI, P.; TRAVAGLIA, A.; MARCELLO, I. Agricultural pesticide-related poisonings in Italy: cases reported to the Poison Control Centre of Milan in 2000-2001. Epidemiol. Prev., v. 28, n.6, p.330-337, 2004.

DONG, X.; SIMON, M.A. The epidemiology of organophosphate poisoning in urban Zimbabwe from 1995 to 2000. Int. J. Occup. Environ. Health, v.7, n.4, p.333-338, 2001.

ECOBICHON, D.J. Toxic effects of pesticides. In: KLAASSEN, C. D. (Ed.). Casarett and Doull's Toxicology - the basic science of poisons. 6.ed. New York: Mc Graw-Hill, 2001.p.763-810.

EDDLESTON, M. Patterns and problems of deliberate selfpoisoning in the developing world. QJM, Quart. J. Med., v.93, n.11, p.715-731, 2000.

EDDLESTON, M.; KARALLIEDDE, L.; BUCKLEY, N.; FERNANDO, R.; HUTCHINSON, G.; ISBISTER, G. Pesticide poisoning in the developing world - a minimum pesticides list. Lancet, v.360, p.1163-1167, 2002.

EMERSON, G.M.; GRAY, M.N.; JELINEK, G.A.; MOUNTAIN, D.; MEAD, H.J. Organophosphate poisoning in Perth, Western Australia, 1987-1996. J. Emerg. Med., v.17, n.2, p.273-277, 1999.

FISHEL, F.; ANDRE, P. Pesticide poisoning symptoms and first aid. MU Guide, University of Missouri 2002. Disponível em: http://muextension.missouri.edu/ explorepdf/agguides/agengin/G01915.pdf. Acesso em: 29 nov. 2006.

HASHIM, S.; RAHIM, D.A.; ALI, R. Surveillance of pesticide poisoning by the Ministry of Health, 1997-2000. NCD Malaysia, v.1, p.4-7, 2002.

IBGE. Instituto Brasileiro de Geografia e Estatística. Censo 2000. Disponível em: http://www.ibge.gov.br/home/ estatistica/populacao/censo $2000 /$ tabelagrandes_regioes211.shtm. Acesso em: 01 out. 2007.

IBGE. Instituto Brasileiro de Geografia e Estatística. Censo 2005. Disponível em: http://www.ibge.gov.br/cidadesat. Acesso em: 29 nov. 2006.
IBGE. Instituto Brasileiro de Geografia e Estatística. Uso de agrotóxicos no Estado do Paraná: safra 1998/1999. Disponível em: http://www.ibge.gov.br/home/estatistica/ economia/agropecuaria/default.shtm. Acesso em: 01 out. 2007.

IPCS News. The Newsletter of the International Programme on Chemical Safety 1993; issue 3:1-8. Disponível em:http://www.who.int/entity/ipcs/publications/ newsletters/en/03.pdf. Acesso em: 29 nov. 2006.

JONES, A.L. Initial management of poisoned patients in the out-of-hospital environment. PreHospital Immed Care, v.2, p.141-149, 1998.

KAMANYIRE, R.; KARALLIEDDE, L. Organophosphate toxicity and occupational exposure. Occup. Med., v.54, n.2, p.69-75, 2004.

KARA, I.H.; GÜLOGLU, C.; KARABULUT, A.; ORAK, M. Sociodemographic, clinical, and laboratory features of cases of organic phosphorus intoxication who attended the emergency department in the Southeast Anatolian Region of Turkey. Environ. Res., Section A, v.88, n.2, p.82-88, 2002.

KARALLIEDDE, L. Organophosphorus poisoning and anaesthesia. Anaesthesia, v.54, n.11, p.1073-1088, 1999.

LU, C.; FENSKE, R.A.; SIMCOX, N.J.; KALMAN, D. Pesticide Exposure of Children in an Agricultural Community: Evidence of Household Proximity to Farmland and Take Home Exposure Pathways. Environ. Res., v.84, n.3, p.290-302, 2000.

MEISTER, R.T. Farm chemicals handbook '99. Willoughby: Meister Publishing Company, 1999, p.12-43,

MIDIO A.F.; SILVA, E.S. Inseticidas-acaricidas organofosforados e carbamatos. São Paulo: Roca, 1995, p.64-70.

NAGAMI, H.; NISHIGAKI, Y.; MATSUSHIMA, S.; MATSUSHITA, T.; ASANUMA, S.; YAJIMA, N. Hospital-based survey of pesticide poisoning in Japan, 1998-2002. Int. J. Occup. Environ. Health, v.11, n.2, p.180-184, 2005. 
NISSE, P.; DEVEAUX, M.; TELLART, A.S.; DHERBECOURT, V.; PEUCELLE, D.; MATHIEUNOLF, M. Aldicarb poisoning: review of cases in the North of France between 1998 and 2001. Acta Clin. Belg., v.1, p.12-15, 2002.

OHAYO-MITOKO, G.J.; KROMHOUT, H.; SIMWA, J.M.; BOLEIJ, J.S.; HEEDERIK, D. Self reported symptoms and inhibition of acetylcholinesterase activity among Kenyan agricultural workers. Occup. Environ. Med., v.57, n.3, p.195-200, 2000.

PIRES, D.X.; CALDAS, E.D.; RECENA, M.C.P. Intoxicações provocadas por agrotóxicos de uso agrícola na microrregião de Dourados, Mato Grosso do Sul, Brasil, no período de 1992 a 2002. Cad. Saúde Pública, v.21, n.3, p.804-814, 2005.

POLASTRO, D. Estudo dos casos de intoxicação ocasionadas pelo uso de agrotóxicos no Estado do Paraná, durante o período de 1993 a 2000. Piracicaba, 2005 116p. [Dissertação de Mestrado. Escola Superior de Agricultura "Luiz de Queiroz". Universidade de São Paulo].

RAGOUCY-SENGLER, C.; TRACQUI, A.; CHAVONNET, A.; DAIJARDIN, J.B.; SIMONETTI, M.; KINTZ, P.; PILEIRE, B. Aldicarb poisoning. Hum. Exp. Toxicol., v.19, n.12, p.657-662, 2000.

ROBERTS, D.M.; FRASER, J.F.; BUCKLEY, N.A.; VENKATESH, B. Experiences of anticholinesterase pesticide poisonings in an Australian tertiary hospital. Anaesth. Intensive Care, v.33, n.4, p.469-476, 2005.

SAADEH, A.M.; AL-ALI, M.K.; FARSAKH, N.A.; GHANI, M.A. Clinical and sociodemographic features of acute carbamate and organophosphate poisoning: a study of 70 adult patients in north Jordan. J. Clin. Toxicol., v.34, n.1, p.45-51, 1996.

SCHVARTSMAN, S.; SCHVARTSMAN, C.; ARGEMÍ, J.; SANCHO, M.J. Informtoxic Fitossanitários - Base de dados toxicológicos sobre fitossanitários. Versão 2.0 for Windows. Brasil: Infofarma, 1997. CD-ROM.
SISTEMA NACIONAL DE INFORMAÇÕES TÓXICOFARMACOLÓGICAS. Casos registrados de intoxicações e/ou envenenamento 2003. Disponível em: http://www.fiocruz.br/ sinitox/2003/brasil2003.htm . Acesso em: 30 jul. 2007.

STALLONES, L.; BESELER, C. Pesticide illness, farm practices, and neurological symptoms among farm residents in Colorado. Environ. Res., v.90, n.2, p.89-97, 2002 .

STALLONES, L.; LEFF, M.; GARRETT, C.; CRISWELL. L.; GILLAN, T. Depressive symptoms among Colorado farmers. J. Agric. Saf. Health, v.1, p.1-5, 1995.

SUNGURTEKIN, H.; GÜRSES, E.; BALCI, C. Evaluation of several clinical scoring tools in organophosphate poisoned patients. Clin. Toxicol., v.44, n.2, p.121-126, 2006.

UNITED Nations Press Release. Farm workers need to be better protected against pesticides: FAO, UNEP call for stronger safety measures 2004. Disponível em: http:// www.un.org/News/Press/docs/2004/sag296.doc.htm. Acesso em: 30 nov. 2006.

VAN DER HOEK, W.; KONRADSEN, F. Analysis of 8000 Hospital admissions for acute poisoning in a rural area of Sri Lanka. Clin. Toxicol., v.44, n.4, p.225-231, 2006.

WEISSMANN-BRENNER, A.; DAVID, A.; VIDAN, A.; HOURVITZ, A. Organophosphate poisoning: a multihospital survey. Israel Med. Assoc. J., v.4, p.573576, 2002.

WOOD, M. Agrochemical service: the world market in 2000. In: ANNUAL REVIEW OF THE CROP PROTECTION ASSOCIATION. Peterborough: Crop Protection Association, 2001.

Recebido para publicação em 27 de novembro de 2007 Aceito para publicação em 13 de março de 2008 